\title{
Octreotide in the treatment of refractory diarrhoea and intestinal fistulae
}

\author{
M J G Farthing
}

\begin{abstract}
Persistent, refractory diarrhoea continues to be an important clinical problem. The mechanisms involved are associated with reduced intestinal absorption and increased intestinal secretion. Reduced intestinal absorption can result from small intestinal resection or from disorders in which there is damage to the small intestine. Motility disorders may also impair absorptive function. The rationale for using octreotide in refractory diarrhoea, intestinal motility disorders, and fistulae relates to its ability to promote intestinal absorption and inhibit gastric, pancreatic, and intestinal secretion. Several clinical studies in patients with short bowel syndrome have reported a reduction of intestinal output in patients taking octreotide compared with controls. Additionally, a number of studies have shown that octreotide improves secretory diarrhoea resulting from neuroendocrine tumours, intestinal infections in AIDS patients, and intestinal graft $v$ host disease. Octreotide may be of use in patients suffering from intestinal motility disorders such as those associated with systemic sclerosis. Octreotide may also be of value in promoting closure of gastrointestinal and pancreatic fistulae.

(Gut 1994; supplement 3: S5-S10)
\end{abstract}

Persistent, refractory diarrhoea continues to be an important clinical problem both in the developing and industrialised world. Persistent diarrhoea in young children is almost invariably associated with undernutrition, but its complex aetiology has not been clearly defined. Infective agents such as the parasites Giardia lamblia and Cryptosporidium parvum are well established causes of persistent diarrhoea but other agents are almost certainly involved. In the industrialised world, chronic infections are less common but continue to be important causes of persistent diarrhoea in immunosuppressed subjects with HIV infection. There is an extensive list of small and large intestinal disorders that cause chronic diarrhoea, which often present diagnostic and treatment problems for clinicians (Table I). Many of these disorders have a specific aetiology, which responds to appropriate treatment but some remain refractory to treatment even though the aetiology may have been defined. This group of refractory diarrhoeas require symptomatic treatment and in many of these the somatostatin analogue, octreotide, has been shown to make an important contribution to management. ${ }^{1}$
TABLE I Major causes of persistent diarrhoea

\begin{tabular}{|c|c|}
\hline \multicolumn{2}{|c|}{ Reduced intestinal absorption } \\
\hline \multirow{7}{*}{ Maldigestion } & Pancreatic insufficiency \\
\hline & Reduced intraluminal bile salts \\
\hline & liver disease \\
\hline & drugs (neomycin) \\
\hline & Bacterial overgrowth \\
\hline & $\begin{array}{l}\text { jejunal diverticula } \\
\text { strictures }\end{array}$ \\
\hline & motility disorders \\
\hline \multirow[t]{11}{*}{ Malabsorption } & Intestinal resection \\
\hline & Mucosal defects \\
\hline & Congenital/inherited \\
\hline & Inflammatory disorders \\
\hline & Crohn's disease \\
\hline & radiation enteritis \\
\hline & $\begin{array}{l}\text { intestinal infections } \\
\text { coeliac disease }\end{array}$ \\
\hline & Lymphatic obstruction \\
\hline & lymphangiectasia \\
\hline & Whipple's disease \\
\hline & $\begin{array}{l}\text { Drugs (laxatives, biguanides, anti-cancer } \\
\text { drugs) }\end{array}$ \\
\hline \multicolumn{2}{|c|}{ Increased intestinal secretion } \\
\hline \multirow{5}{*}{$\begin{array}{l}\text { Neuroendocrine } \\
\text { tumours }\end{array}$} & Zollinger-Ellison syndrome \\
\hline & VIPoma \\
\hline & Somatostatinoma \\
\hline & Carcinoid syndrome \\
\hline & Medullary thyroid carcinoma \\
\hline Infection & HIV, AIDS related diarrhoea \\
\hline Congenital defects & $\begin{array}{l}\text { Chloridorrhoea, sodium secretory } \\
\text { diarrhoea }\end{array}$ \\
\hline $\begin{array}{l}\text { Inflammatory } \\
\text { disorders }\end{array}$ & $\begin{array}{l}\text { Inflammatory bowel diseases, graft } v \text { host } \\
\text { disease }\end{array}$ \\
\hline Drugs & Laxatives \\
\hline
\end{tabular}

Intestinal losses of fluid, electrolytes, digestive enzymes, and nutrients may also occur through enterocutaneous fistulae. Most high output fistulae will require surgical treatment, but intestinal losses can be reduced dramatically by octreotide particularly when used in association with intravenous nutrition. As will become evident, the rationales for using octreotide in both refractory diarrhoea and in high output of intestinal fistulae are similar.

\section{Definition of persistent, refractory diarrhoea}

The definition of persistent diarrhoea is usually arbitrarily taken as diarrhoea lasting more than 14 days. The definition of diarrhoea should not be based on stool frequency alone, but should include increased stool volume (or weight). Normal faecal weight varies in different regions of the world depending on diet. In the United Kingdom, more than $200 \mathrm{~g} / 24$ hours is regarded as increased stool weight. In West Africa where the traditional diet has a much higher fibre content, normal stool weight may reach $350-400 \mathrm{~g} / 24$ hours. Before establishing a diagnosis of persistent diarrhoea, stool volume should be measured and shown to be greater than the faecal output of healthy volunteers in the same geographical location. The term refractory is used to describe diarrhoea that has failed to respond either to specific treatment for a condition of known
Department of Gastroenterology, St Bartholomew's 
aetiology or a failure to respond adequately to standard antidiarrhoeal preparations in conventional doses.

\section{Pathophysiology of increased losses from the gastrointestinal tract}

The mechanisms participating in the production of persistent diarrhoea can be broadly classified into those that are predominantly associated with (a) reduced intestinal absorption and (b) increased intestinal secretion. These categories, however, are not mutually exclusive; in some disorders such as Crohn's disease there may be a combination of the two. During a normal day about nine litres of fluid enter the upper gastrointestinal tract. Secretions from salivary glands, stomach, pancreas, and biliary tract contribute about seven litres and between 1.5-2 litres are taken in food and drink. About 1.5 litres leave the small bowel and enter the colon, the remainder having been absorbed by the small intestine. Small intestinal absorption is maximal two to three hours after a meal, whereas colonic absorption continues throughout the 24-48 hour period of colonic transit. Ninety per cent of the fluid entering the colon is absorbed, resulting in an average stool volume of $0 \cdot 15$ litres. The colon can increase its absorptive capacity two to threefold but when this is exceeded diarrhoea follows.

\section{DECREASED ABSORPTION}

It is evident from the description of fluid movement in and out of the intestinal tract, that any loss of absorptive components of the system can result in diarrhoea (Table I). A simple example of this is extensive small intestinal resection. Subjects with a residual length of $150 \mathrm{~cm}$ of jejunum or less are likely to have diarrhoea. This is caused simply by a failure to absorb the basal and meal stimulated secretions that enter the small intestine every 24 hours. ${ }^{2}{ }^{3}$ Despite a short small intestine some patients can still absorb more than their oral intake (net absorbers) and in general these subjects have more than $100 \mathrm{~cm}$ of residual small intestine. Some, however, have an intestinal effluent that exceeds oral intake (net secretors) and almost invariably have a residual small intestinal length of less than $80-100 \mathrm{~cm}^{2}$ The colon is of vital importance to subjects with a short small intestine, its presence leading to a reduction in intestinal effluent from about 5 litres $/ 24$ hours to about $1 \cdot 5-2$ litres $/ 24$ hours and being equivalent to about $50 \mathrm{~cm}$ of small intestine.

Enterocutaneous fistulae are no different, pathophysiologically, from a high jejunostomy after intestinal resection. The fistula effectively bypasses the small intestine and colon, leading to loss of basal and meal stimulated secretions from the upper small intestine. The more distal the fistula, the lower the output and thus the clinical significance of the losses is reduced. The volume of fistula losses will also be determined by the calibre of the fistula, as this will have an impact on flow rates.
TABLE II Inflammatory mediators and neurotransmitters that modulate intestinal transport

Inflammatory mediators of intestinal secretion

Prostaglandins $\left(\mathrm{PGE}_{2}, \mathrm{PGF}_{2 \alpha}\right)$

Leukotrienes $\left(\mathrm{LTD}_{4}, \mathrm{LTE}_{4}, 5\right.$-HPETE, 5-HETE)

Kinins (bradykinin)

Histamine ( $\mathrm{H}_{1}$ receptors $)$

Secretory neurotransmitter

Acetylcholine

Vasoactive intestinal peptide

Peptide histidine-methionine

Substance P

5-HT

Persistent diarrhoea caused by impaired intestinal absorption occurs in many disorders, particularly those that result in damage to the small intestine with disruption of villous architecture, including conditions such as coeliac disease, tropical sprue, giardiasis, and rotavirus infection. Motility disorders may also impair absorptive function and may be an important component of some infective and inflammatory diarrhoeas caused by the release of local mediators such as prostaglandins, 5hydroxytryptamine (5-HT), and other smooth muscle agonists (Table II).

\section{INCREASED INTESTINAL SECRETION}

The classic secretory diarrhoeas (cholera, enterotoxigenic $E$ coll) are acute and generally self limiting, providing adequate fluid and electrolyte support is given. Intestinal secretion, however, is also important in a number of persistent diarrhoeas particularly those associated with the release of inflammatory mediators within the intestinal wall that stimulate secretion of fluid and electrolytes (Table II). Bradykinin, a substance liberated in many inflammatory reactions within the gut, releases arachidonic acid metabolites such as prostaglandins and leukotrienes from subepithelial lymphocytes. Some prostaglandins such as $\mathrm{PGE}_{2}$ and $\mathrm{PGF}_{2}$ interact with specific receptors on the basolateral membrane of enterocytes and activate secretory pathways. These mediators may contribute to the diarrhoea in inflammatory bowel diseases and almost certainly play an important part in diarrhoea associated with intestinal anaphylaxis as a result of sensitisation to food or parasite antigens. Other classic secretagogues include vasoactive intestinal polypeptide, the important bioactive substance released from VIPomas, and 5-HT, an important mediator in the carcinoid syndrome. These and other secretagogues are also present in the enteric nervous system where they act as secretory neurotransmitters. Other secretory neurotransmitters present within the submucosal and myenteric plexuses include acetylcholine, substance $P$, and peptide histidine-methionine (Table II).

The effects of these secretagogues rely on the activation of second messengers, which for cholera toxin, vasoactive intestinal polypeptide, and $\mathrm{PGE}_{2}$ is cyclic AMP. 5-HT, substance $P$, and histamine activate the enzyme phospholipase $\mathrm{C}$, which produces another set of second messengers namely, inositol triphosphate and diacyl glycerol. 
TABLE III Octerotide in short bowel syndrome: short term studies

\begin{tabular}{|c|c|c|c|c|c|}
\hline Study (ref) & $\begin{array}{l}\text { Patients } \\
\text { (n) }\end{array}$ & $\begin{array}{l}\text { Intestinal } \\
\text { length } \\
(\mathrm{cm})\end{array}$ & $\begin{array}{l}\text { Dose } \\
\text { octreotide }\end{array}$ & $\begin{array}{l}\text { Intestinal } \\
\text { output } \\
\text { (litre/24 hours) }\end{array}$ & $\begin{array}{l}\text { \% Reduction } \\
\text { with } \\
\text { octreotide }\end{array}$ \\
\hline 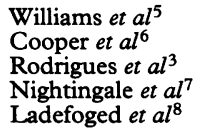 & $\begin{array}{l}1 \\
5 \\
4 \\
6 \\
6\end{array}$ & $\begin{array}{l}\text { Not stated } \\
\text { Not stated } \\
30-120 \\
25-70 \\
40-225\end{array}$ & $\begin{array}{l}100 \mu \mathrm{g} / 24 \text { hours } \\
25 \mu \mathrm{g} / \mathrm{hour} \\
50 \mu \mathrm{g} / 6 \text { hours } \\
100-300 \mu \mathrm{g} / 24 \text { hours } \\
25 \mu \mathrm{g} / \text { hour }\end{array}$ & $\begin{array}{l}4-6 \\
4-7 \\
2-5 \\
3 \cdot 7-7 \cdot 0 \\
2 \cdot 3-8 \cdot 2\end{array}$ & $\begin{array}{l}40-50 \\
20 \\
\text { About } 50 \\
16-72 \\
\text { About } 50\end{array}$ \\
\hline
\end{tabular}

Rationale for the use of octreotide in refractory diarrhoea and fistulae

Somatostatin and its long acting analogue, octreotide, inhibit intestinal motility, the most profound effects being in the small intestine. ${ }^{1}$ Octreotide also inhibits gastric and pancreatic secretion and intestinal secretion resulting from vasoactive intestinal polypeptide, $\mathrm{PGE}_{2}$, and 5HT. Finally, octreotide inhibits the release of gut peptides such as vasoactive intestinal polypeptide and peptide histidine-methionine and other mediators of diarrhoea including 5HT. ${ }^{1}$ Octreotide also reduces splanchnic blood flow, which can also have secondary effects on intestinal absorption and secretion.

Octreotide acts by cAMP dependent and independent mechanisms. Octreotide may influence intestinal secretory function by modulating calcium fluxes. Octreotide binds to somatostatin receptors, which have been identified on a variety of cell types including pancreatic exocrine cells, islet cells secreting insulin, glucagon, and somatostatin and gastric parietal and small intestinal epithelial cells. Octreotide is thought to act by inhibiting adenylate cyclase activity by activating the inhibitory guanine nucleotide (GTP binding protein, $G_{i}$ ), which is located on the basolateral membrane of the enterocyte in close proximity to the somatostatin receptor.

\section{Octreotide in refractory diarrhoea: clinical studies}

\section{DIARRHOEA RESULTING FROM DECREASED INTESTINAL ABSORPTION}

\section{Short bowel syndrome}

Dharmsathaphorn et al first reported the beneficial effects of native somatostatin infusion in patients with short bowel syndrome. ${ }^{4}$ Four patients were reported on with stomal outputs of about $2 \mathrm{~kg} / 24$ hours. Somatostatin infusion at $4 \mu \mathrm{g} / \mathrm{min}$ reduced intestinal effluent by about $35 \%$. After this report there were a series of studies with small numbers of patients in which octreotide was given either by infusion or bolus doses and the effect on net fluid and electrolyte absorption assessed $^{3 \text { 5-8 }}$ (Table III).

TABLE IV Octerotide in short bowel syndrome: longterm studies

\begin{tabular}{|c|c|c|c|c|c|}
\hline Study (ref) & $\begin{array}{l}\text { Patients } \\
\text { (n) }\end{array}$ & $\begin{array}{l}\text { Dose } \\
\text { octreotide } \\
\text { ( } \mu g / 24 \text { hours) }\end{array}$ & $\begin{array}{l}\text { Duration } \\
\text { (mth) }\end{array}$ & $\begin{array}{l}\text { Reduction in } \\
\text { intestinal } \\
\text { output } \\
\text { maintained (\%) }\end{array}$ & $\begin{array}{l}\text { Adverse } \\
\text { effects }\end{array}$ \\
\hline $\begin{array}{l}\text { Cooper et al } \\
\text { Nightingale } e t a l^{7} \\
\text { Ladefoged } \text { et } a l^{8}\end{array}$ & $\begin{array}{l}2 \\
2 \\
4\end{array}$ & $\begin{array}{l}100 \\
100 \\
100\end{array}$ & $\begin{array}{l}4-6 \\
12 \\
21-28\end{array}$ & $\begin{array}{r}100 \\
100 \\
75\end{array}$ & $\begin{array}{l}\text { None reported } \\
\text { None reported } \\
\text { None reported }\end{array}$ \\
\hline
\end{tabular}

These reports contain a heterogeneous group of patients with noticeable variation in the residual intestinal length and not surprisingly a broad range of intestinal output (2.0-8.2 litres $/ 24$ hours). Nevertheless all studies reported a reduction in intestinal output varying between $16-72 \%$ of the drug free control period. Sodium and generally potassium losses were also reduced, the second being consistent with the hypothesis that octreotide not only inhibits secretion but also promotes absorption of fluid and electrolytes. Octreotide has also been shown to reduce ileostomy diarrhoea in infants and children. ${ }^{9} 10$

There is some evidence to suggest that octreotide may in some patients not only reduce fluid and electrolyte losses but also improve energy balance by $20-50 \% .^{3} \mathrm{~A}$ second study failed to produce such encouraging results, however, although one patient was converted from negative to positive energy balance during octreotide treatment. ${ }^{7}$ The effects of octreotide on intestinal output can be maintained for many months at a dose of 100 $\mu \mathrm{g} / 24$ hours $^{6-8}$ (Table IV). No adverse effects were reported in this small group of patients.

Octreotide would seem to exert its beneficial effects in short bowel syndrome not by slowing gastric emptying, 56 but by retarding small intestinal transit thus optimising absorption of fluid and electrolytes. ${ }^{6}$ Octreotide also reduces secretions into the upper gastrointestinal tract, particularly gastric and pancreatic secretions. ${ }^{11}$

\section{Congenital microvillous atrophy}

Octreotide $100 \mu \mathrm{g}$ twice daily reduced faecal sodium, potassium, and chloride losses and increased urinary output and urinary sodium excretion in a young child with this rare condition. ${ }^{12}$

\section{DIARRHOEA RESULTING FROM INCREASED INTESTINAL SECRETION}

Octreotide has been shown to improve secretory diarrhoea resulting from neuroendocrine tumours and a variety of infective and inflammatory conditions of the intestine.

\section{Neuroendocrine tumours}

VIPomas - after a report that somatostatin could control diarrhoea in a patient with a VIPoma ${ }^{13}$ a series of studies with octreotide $100-300 \mu \mathrm{g} / 24$ hours showed reductions in stool output from several litres to normal or near normal stool volumes. ${ }^{14-17} \mathrm{Up}$ to $90 \%$ of patients with VIPoma can expect to respond, with the effects maintained long term. Vasoactive intestinal polypeptide plasma concentrations decreased in about $60 \%$ of patients, although a reduction in plasma vasoactive intestinal polypeptide does not necessarily correlate with symptomatic benefit. ${ }^{17}$

Carcinoid tumours - 5-HT, an important product of carcinoid tumours, is a potent intestinal secretagogue and prokinetic agent. Carcinoid tumours also secrete hormonal and vasoactive substances such as bradykinin, 
substance $P$, neurokinin A, neuropeptide $K$, and prostaglandins. Somatostatin infusion reduces carcinoid diarrhoea, ${ }^{18}$ as does octreotide at doses of $50-1000 \mu \mathrm{g} / 24$ hours. ${ }^{19-24}$ Response rates for diarrhoea are $60-90 \%$ and reduction in flushing episodes is usually achieved. In addition there is often an appreciable general improvement in health with increased appetite and weight gain. ${ }^{25}$

Gastrinoma - octreotide inhibits gastrin release and reduces diarrhoea in patients with gastrinoma. ${ }^{2627}$ Symptomatic control, however, is usually achieved with a proton pump inhibitor, but octreotide remains an alternative treatment should other measures fail or are not tolerated.

\section{Intestinal infection}

High volume watery diarrhoea often accompanies AIDS. A number of small, uncontrolled studies in patients with AIDS, usually infected by Cryptosporidium parvum, have shown that octreotide 50-1500 $\mu \mathrm{g} / 24$ hours in divided doses can reduce stool frequency and stool volumes in some, but not all patients. ${ }^{1}$ Cello et $a l^{28}$ performed a multicentre, open label clinical trial of octreotide in 49 AIDS patients with refractory high volume diarrhoea who had not responded to conventional antidiarrhoeal treatment. During 14 days treatment, octreotide (150-1000 $\mu \mathrm{g} / 24$ hours) reduced stool volume and stool frequency. Only four patients $(8 \%)$, however, obtained a complete remission with normal stool volume and 13 patients $(27 \%)$ experienced a partial response with a $50 \%$ reduction in stool volume. Diarrhoea returned in all patients when octreotide was stopped.

Octreotide in HIV infection and AIDS related diarrhoea has been evaluated further in multicentre studies in North America and Europe. ${ }^{1}$ Octreotide was given in increasing doses from $150-1500 \mu \mathrm{g} / 24$ hours to 77 patients, more than half of whom had enteropathogens identified including Cryptosporidium parvum, cytomegalovirus, Isospora belli, and Giardia lamblia. There were 61 evaluable patients, 10 of whom had a complete response $(17 \%)$ and 17 a partial response $(28 \%)$, giving an overall response rate of $45 \%$. In the responders, octreotide reduced stool frequency and stool volume, and there was improvement in the quality of life.

The mechanisms by which octreotide improves AIDS related diarrhoea has not been studied in detail although it seems possible that it is related to its ability to promote fluid and electrolyte absorption and to prolong small intestinal transit.

\section{Intestinal graft $\mathrm{v}$ host disease}

The intestinal tract is a target for graft $v$ host disease after bone marrow transplantation. Diarrhoea can be severe with high stool volumes and associated undernutrition. Conventional antidiarrhoeal agents are often ineffective. Octreotide 300-1200 $\mu \mathrm{g} / 24$ hours has been used in the treatment of high volume diarrhoea ( 3 litres/24 hours) in a patient with intestinal graft $v$ host disease with a $50 \%$ reduction in stool volume. Diarrhoea returned when octreotide was stopped and was controlled again when reintroduced. ${ }^{29}$

\section{DIARRHOEA RELATED TO INTESTINAL MOTILITY DISORDERS}

\section{Diabetes mellitus}

Disturbance of bowel function is common in patients with diabetes mellitus with persistent diarrhoea occurring in up to $20 \%$ of patients, usually in association with autonomic neuropathy. Diarrhoea can be severe and debilitating and cause a severe deterioration in quality of life. Several case reports suggest that octreotide $150-300 \mu \mathrm{g} / 24$ hours can reduce high volume diarrhoea from several litres/24 hours to less than one litre. ${ }^{30-33}$ The effect can be maintained for many months and is often associated with a considerable improvement in the quality of life. Additional benefits such as improvement in postural hypotension and a reduction in insulin requirements may also be seen.

\section{Coeliac plexus block}

Watery diarrhoea has been reported in two patients after coeliac plexus block. ${ }^{33}$ It was assumed that this was related to acute sympathetic denervation of the small and large intestine. Octreotide (200 $\mu \mathrm{g} / 24$ hours) reduced stool frequency and normalised stool consistency in one patient. ${ }^{33}$

\section{Systemic sclerosis}

Gastrointestinal involvement is common in patients with systemic sclerosis. Fifty per cent experiencing some form of small bowel dysfunction. Impaired small bowel motility predisposes to bacterial overgrowth with associated diarrhoea and intestinal malabsorption. Octreotide restored migrating motor complexes in patients with systemic sclerosis, reduced bacterial overgrowth, and improved abdominal symptoms including nausea, bloating, and abdominal pain. ${ }^{34}$

\section{Irritable bowel syndrome}

A patient with acromegaly and irritable bowel syndrome, which was diagnosed before the onset of acromegaly, was treated with somatostatin. ${ }^{35}$ There was rapid relief of the abdominal symptoms, which was thought to be independent of the treatment of acromegaly. It might be hypothesised that irritable bowel syndrome is associated with a degree of 'somatostatin deficiency', but fasting and meal stimulated concentrations of plasma somatostatin are normal in patients with this condition. ${ }^{36}$ Octreotide does, however, have a profound inhibitory effect on small intestinal transit both in healthy subjects and in patients with diarrhoea predominant irritable bowel syndrome. ${ }^{37}$ Although this case is of interest, 
the widespread use of octreotide cannot be recommended for patients with irritable bowel syndrome, although a therapeutic trial might be considered in patients with severe, intractable symptoms in whom all other treatment has failed.

\section{Octreotide in gastrointestinal and pancreatic fistulae}

The first indication that octreotide might be of value in promoting closure of gastrointestinal and pancreatic fistulae came from the early uncontrolled studies with native somatostatin. More than 150 patients have been reported by many investigators. Overall fistula output was reduced by $50-90 \%$ and closure of the fistula was judged to have been enhanced in about $80 \%$ of the patients treated. ${ }^{1}$ In general, somatostatin was used as adjunctive treatment in combination with intravenous nutrition, with fistula closure occurring in 5-11 days. It must be remembered, however, that spontaneous fistula closure occurs in patients receiving intravenous nutrition, providing there is no distal obstruction or ongoing intestinal injury and therefore the results of uncontrolled studies must be evaluated critically.

Because of these apparently encouraging results, octreotide has been used in a large number of patients with fistulae with more than 130 such patients reported in published works. Most are case reports of small numbers of patients without adequate control data. ${ }^{1}$ Octreotide has been used at doses of 100-600 $\mu \mathrm{g} / 24$ hours and most studies report at least a $50 \%$ reduction in fistula output during the first 24 hours. Closure time varies enormously and it is almost impossible to come to any firm conclusions as to whether time to closure was significantly reduced by the use of octreotide. It seems possible, however, that reduction in fistula output will have nutritional benefits and make fluid, electrolyte, and nutrient losses earlier to treat.

\section{Pancreatic fistulae}

One prospective randomised study of 16 patients with pancreatic ascites has been reported. Octreotide $200 \mu \mathrm{g} / 24$ hours was given with intravenous nutrition and the results compared with a group of patients receiving intravenous nutrition alone. Fistula closure occurred in six of eight patients in each group although the time to closure was significantly reduced in the octreotide group (13 $v 32$ days) $(p<0.0001)$ as was the length of hospital stay (17 $v 36$ days ) $(\mathrm{p}<0.0001) .{ }^{38}$ Other case reports suggest that octreotide does have a beneficial effect in pancreatic ascites, pancreatopleural diffusions, and in the treatment of pancreatic pseudocysts. ${ }^{1}$

\section{Enterocutaneous fistulae}

Information on closure of enterocutaneous fistulae is again difficult because of the lack of controlled studies. Encouraging results were obtained in an uncontrolled study of postoperative enterocutaneous fistula in which 27 patients were treated with octreotide 300 $\mu \mathrm{g} / 24$ hours and the fistula output and time to fistula closure assessed. ${ }^{39}$ Fistula output decreased by an average of $55 \%$. Fistula closure occurred in 21 of 27 patients $(77 \cdot 7 \%)$ after a mean of $5 \cdot 8$ days. The same group performed a blind crossover study in 14 patients with small bowel fistula treated with octreotide 225-300 $\mu \mathrm{g} / 24$ hours for two days and compared with a similar period on placebo. ${ }^{40}$ Octreotide significantly reduced fistula output compared with placebo $(\mathrm{p}<0.025)$. Eleven of $14(79 \%)$ had fistula closure in $2-10$ days.

1 Harris AG. Octreotide in the treatment of disorders of the gastrointestinal tract. Drug Investigation 1992; 4 (suppl 3): $1-54$.

2 Nightingale JMD, Lennard-Jones JE, Walker ER, Farthing MJG. Jejunal efflux in short bowel syndrome. Lancet 1990; 336: 765-8.

3 Rodrigues CA, Lennard-Jones JE, Thompson DG, Farthing MJG. The effects of octreotide, soy polysaccharide, codeine and loperamide on nutrient, fluid and electrolyte absorption in the short bowel syndrome. Aliment Pharmacol Therap 1989; 3: 159-69.

4 Dharmsathaphorn K, Gorelick FS, Sherwin RS, Cataland $S$, Dobbins JW. Somatostatin decreases diarrhea in patients with the short bowel syndrome. $f$ Clin Gastroenterol 1982; 4: 521-4.

5 Williams NS, Cooper JC, Axon ATR, King RFGJ, Barker $M$. Use of a long-acting somatostatin analogue in controlling life threatening ileostomy diarrhoea. $B M F$ 1984; 289: 1027-8.

6 Cooper JC, Williams NS, King RFGJ, Barker MCJ. Effects of a long-acting somatostatin analogue in patients with

Nightingale JMD, Walker ER, Burnham WR, Farthing MJG, Lennard-Jones JE. Octreotide (a somatostatin analogue) improves the quality of life in some patients analogue) improves the quality of life in some patients with a shor

8 Ladefoged K, Christensen KC, Hegnhøj J, Jarnum S. Effect of a long-acting somatostatin analogue SMS 201-995 on jejunostomy effluents in patients with severe short bowe syndrome. Gut 1989; 30: 943-9.

9 Ohlbaum P, Galperine RI, Demarquez IL, Vergnes P, Martin C. Use of a long-acting somatostatin analogue (SMS 201-995) in controlling a significant ileal output in a 5 year old child. $\mathcal{f}$ Pediatr Gastroenterol Nutr 1987; 6: a 5 year

10 Lamireau T, Galperine RI, Ohlbaum P, et al. Use of a longacting somatostatin analogue in controlling ileostomy

11 Nightingale JMD, Walker ER, Farthing MJG, LennardJones JE. Effect of omeprazole on intestinal output in the short bowel syndrome. Aliment Pharmacol Therap 1991; 5: 405-12.

12 Couper RTL, Berzen A, Berall G, et al. Clinical response to the long acting somatostatin analogue octreotide in a child with congenital microvillus atrophy. Gut 1989; 30: $1020-4$.

13 Ruskone A, Rene E, Chayvlalle JA, et al. Effect of somatostatin on diarrhoea and on small intestinal water and electrolyte transport in a patient with pancreatic cholera. Dig Dis Sci 1982; 27: 459-66.

14 Maton PM, O'Dorisio TM, Howe BA, et al. Effect of a long-acting somatostatin analogue (octreotide) in patients

15 Santangelo WC, Dueno MI, Krejs BJ. Pseudopancreatic cholera syndrome: effect of a synthetic somatostatin analogue, SMS 201-995. Am f Med 1987; 82: 84-7.

16 Eriksson B, Oberg K, Andersson T, et al. Treatment of malignant endocrine pancreatic tumours with a new longacting somatostatin analogue, octreotide. Scand Gastroenterol 1988; 23: 508-12.

17 Gorden P, Comi RJ, Matron PN, et al. Somatostatin and somatostatin analogue (SMS 201-995) in treatment of hormone-secreting tumours of the pituitary and gastrointestinal tract and non-neoplastic diseases of the gut. Ann Intern Med 1989; 110: 35-50.

18 Dharmsathaphorn $\mathrm{K}$, Sherwin RS, Cataland S, et al. Somatostatin inhibits diarrhea in the carcinoid syndrome. Somatostatin inhibits diarrhea in
Ann Intern Med 1980; 92: 68-9.

19 Richter G, Stockmann B, Conlon JM, et al. Short-term administration of the somatostatin analogue octreotide in patients with carcinoid tumours. Scand $\mathcal{f}$ Gastroenterol 1986; 21: 193-8S

20 Souquet JC, Sassolas G, Forichon J, et al. Clinical and hormonal effects of a long-acting somatosatin analogue in pancreatic endocrine tumors and in carcinoid syndrome. Cancer 1987; 59: 1654-60.

21 Kvols LK, Moertel CG, O'Connell MJ, et al. Treatment of the malignant carcinoid syndrome: evaluation of a longacting somatostatin analogue. $N$ Engl f Med 1986; 315: 663-6. 
22 Vinik AI, Moattari AR. Use of somatostatin analog in management of carcinoid syndrome. Dig Dis Sci 1989; 34 (suppl): 14-27

23 Chayvialle JA. Sandostatin and carcinoid tumours in France: experience in the Lyon area. Digestion 1990; 40 (suppl 1): 23-6.

24 Woods HF, Bax NDS, Ainsworth I. Abdominal carcinoid tumours in Sheffield Digestion 1990; 4 (suppl 1): 17-22. tumours in Sheffield. Digestion 1990; 4 (suppl 1): 17-22.

5 Smith S, Anthony L, Roberts LJ, et al. Resolution of musculoskeletal symptoms in the carcinoid syndrome after treatment with the somatostatin analog octreotide. Ann Intern Med 1990; 112: 66-8.

26 Vinik AI, Tsai ST, Moattari AR, et al. Somatostatin analogue (SMS 201-995) in the management of gastroenteropancreatic tumors and diarrhea syndromes. $\mathrm{Am} \mathfrak{F}$ Med 1986; 81 (suppl 6B): 23-40.

27 Mozell E, Woltering EA, O'Dorisio TM, et al. Effect of somatostatin analog on peptide release and tumor growth in the Zollinger-Ellison syndrome. Surg Gynecol Obstet 1990; 170: 476-84.

28 Cello JP, Grendell J, Basuk P, et al. Controlled clinical trial of octreotide for refractory AIDS-associated diarrhoea. Gastroenterology 1990; 98 (suppl 1): A163.

29 Bianco JA, Higano C, Singer J, et al. The somatostatin analog octreotide in the management of the secretory analog octreotide in the management of the secretory diarrhea of the acute intestinal graft-versus-host disease in a patient after bone ma

30 Tsai S-T, Vinik AI, Brunner JF. Diabetic diarrhoea and somatostatin. Ann Intern Med 1986; 104: 894

31 Dudi RJ, Anderson DS, Forsythe AB, et al. Treatment of diabetic diarrhea and orthostatic hypotension with somatostatin analogue octreotide. Am f Med 1987; 83; $584-8$

32 Mourad FH, Gorard D, Thillainayagam AV, Colin-Jones D, Farthing MJG. Effective treatment of diabetic diarrhoea with the somatostatin analogue, octreotide. Gut 1992; 33: 1578-80.

33 Dean AP, Reed WD. Diarrhoea - un unrecognised hazard of coeliac plexus block. Aust NZ f Med 1991; 21 : 47-8.

34 Soudah HC, Hasler WL, Owyang CH. Effect of octreotide on intestinal motility and bacterial overgrowth in scleroon intestinal motility and bacterial overgrod

35 Talley NJ, Turner I, Middleton WR. Somatostatin and symptomatic relief of irritable bowel syndrome. Lancet ii: 1114.

36 O'Donnell LJ, Wass JA, Farthing MJG. Plasma somatostatin concentrations in irritable bowel syndrome. Aliment Pharmacot Therap 1991; 5: 659-63.

37 O'Donnell LJ, Watson AMJ, Cameron D, Farthing MJG. Effect of octreotide on mouth-to-caecum transit time in healthy subjects and in the irritable bowel syndrome. Aliment Pharmacol Therap 1990; 4: 177-81.

38 Haffejee AA, Singh B, Simjee AE Somatostatin in the management of internal pancreatic fistula. Gastroenterology 1991; 100 (suppl): A274.

39 Nubiola P, Badia JM, Martinez-Rodenas F, et al. Treatment of 27 post-operative enterocutaneous fistulas with the long, half-life somatostatin analogue SMS 201-995. Ann Surg 1989; 210: 56-8.

40 Nubiola-Calonge P, Badia JM, Sancho J, et al. Blind evaluation of the effects of octreotide (SMS 201-995), a somatostatin analogue, on small bowel fistula output. Lancet 1987; ii: $672-4$. 